\title{
Extent of Scientific Temperament of Pulse Growers towards Cluster Demonstration in Rewa District M.P., India
}

\author{
Kulraj Raghuwanshi*, Seema Naberia and M.K. Dubey
}

Department of Extension Education, College of Agriculture Jawaharlal Nehru Krishi Vishwa Vidyalaya, Jabalpur, Madhya Pradesh India

*Corresponding author

\section{A B S T R A C T}

Agricultural innovations and diffusion of new technologies are key drivers to achieve food security in the country besides providing farmers a competitive edge over traditional

\section{Keywords}

Cluster demonstration, Scientific temperament, Pulse growers, Krishi

Vigyan Kendra

Article Info

Accepted:

17 July 2018

Available Online:

10 August 2018 farming, thus facilitating better standards of living. In this context, cluster demonstrations is a novel approach to provide direct interface between scientists and farmers in planning, execution \& monitoring phases of the demonstrations. Indian council of Agricultural Research (ICAR) has launched Cluster Demonstrations Programme on pulse and oilseed crops in the year 2015-2016. The KVKs are the real carriers of frontline technologies and impart knowledge and critical input support for the famers. The present study was carried out with the aims to know the extent of scientific temperament of pulse growers towards cluster demonstration during 2017-18 in the 6 villages of Rewa district of Madhya Pradesh. A total 120 pulse growers were selected randomly as respondents. The data collection was done by the use of interview schedule personal interview. The finding of the study depict that majority of the pulse growers $(44.17 \%)$ had low scientific temperament level and in practice wise scientific temperament the mean score was found highest in summer time of sowing (1.46) followed by use of improved variety of pulses.

\section{Introduction}

Pulses are an important commodity group of crops that provide high quality protein complementing cereal proteins for predominantly substantial vegetarian population of our country. Being the largest producer of pulses, India accounts for $33 \%$ of the world area and $22 \%$ of the world production of pulses. In India, Madhya Pradesh is the largest producer of pulses followed by Maharashtra, Rajasthan, Uttar Pradesh, Andhra Pradesh and Karnataka.
Indian Council of Agriculture Research initiated Front Line Demonstrations on pulses \& oilseed crops in the year 1990-1991. This programme was conducted by Krishi Vegan Kendra and showed a great impact on enhancement of yield potential of pulse crops. Realising the importance of such type of technology dissemination programme, through Cluster approach, Indian council of Agricultural Research (ICAR) has launched Cluster Demonstrations Programme on pulse and oilseed crops in the year 2015-2016.In context to Rewa district, pulses being 
predominant crops, occupy an area of 0.7443 lakh ha. with production $109.70 \mathrm{mt}$. tonnes. With a view to enhance the area and productivity of pulses several initiatives has been undertaken by the Madhya Pradesh state government. Krishi Vigyan Kendra, Rewa has also been conducting cluster demonstrations since 2015-2016 on major pulses crops of the region.

KVKs are grass root level organizations meant for application of technology through assessment, refinement and demonstration of proven technologies under different micro farming situations in a district the main objective of cluster demonstration is to show the worth or value of the technology. One of the major objectives of these demonstrations is to inculcate desired scientific temperament of the farming community.

\section{Materials and Methods}

The present study was carried out during 2017-18 in the Rewa district of Madhya Pradesh. Krishi Vigyan Kendra Rewa has been conducting cluster demonstration on pulses since 2015-2016. These demonstrations have been carried out in four blocks of Rewa district viz. Rewa, Naigarhi, Sirmour, and Raipur Karchulian. Out of which Rewa block was selected purposively. A list of villages was obtained from the Krishi Vigyan Kendra Rewa where Cluster demonstration has been carried out and six villages were selected on the basis of maximum no. of pulse growers. Total 120 respondents were selected randomly from all selected villages. Respondents were interviewed through personal interview. For the data collection well designed and pretested interview scheduled were used.

In the present study, extent of scientific temperament refers to the knowledge about recommended practices and new techniques used in cultivation of pulse crop. For measuring extent of knowledge of the beneficiaries, a list of logical practices recommended for pulses crop was prepared. Krishi Vigyan Kendra Rewa has conducted cluster demonstration on green gram, pigeon pea, and lentil. Hence only these crops were considered in the study.

\section{Results and Discussion}

The table 1 shows that out of total respondents, 44.17 per cent had low scientific temperament level, followed by 31.67 per cent had medium and only 24.16 per cent had high scientific temperament of cluster demonstration.

Table.1 Distribution of respondents according to their scientific temperament

\begin{tabular}{|r|l|l|l|}
\hline S. N. & Extent of scientific temperament & Frequency & Percentage \\
\hline 1. & Low(up to 18 score) & 53 & 44.17 \\
\hline 2. & Medium(19 to 26 score) & 38 & 31.67 \\
\hline 3. & High(above 26 score) & 29 & 24.16 \\
\hline Total & 120 & 100.00 \\
\hline
\end{tabular}


Table.2 Practice wise scientific temperament of pulse grower $(\mathrm{N}=120)$

\begin{tabular}{|l|l|l|l|l|l|l|l|l|}
\hline \multirow{2}{*}{ S. N. } & Statement & Level of scientific temperament & Total & $\begin{array}{l}\text { Mean } \\
\text { Score }\end{array}$ & Rank \\
\hline $\mathbf{1}$ & Complete & Partial & Incomplete & score & Score \\
\hline $\mathbf{2}$ & Selection of land & 55 & 35 & 30 & 145 & 1.20 & IV \\
\hline $\mathbf{3}$ & Summer sowing time & 68 & 40 & 12 & 176 & 1.46 & I \\
\hline $\mathbf{4}$ & Use of improved varieties & 64 & 42 & 14 & 170 & 1.41 & II \\
\hline $\mathbf{5}$ & Appropriate seed rate & 58 & 47 & 15 & 163 & 1.35 & III \\
\hline $\mathbf{6}$ & Seed treatment & Plant distance & 31 & 41 & 28 & 143 & 1.19 & V \\
\hline $\mathbf{7}$ & Manure \& fertilizers & 44 & 42 & 43 & 112 & 0.93 & XI \\
\hline $\mathbf{8}$ & Weed management & 43 & 48 & 27 & 134 & 1.11 & VII \\
\hline $\mathbf{9}$ & Insect \& pest management & 41 & 40 & 39 & 122 & 1.01 & IX \\
\hline $\mathbf{1 0}$ & Disease management & 38 & 42 & 40 & 118 & 0.98 & X \\
\hline $\mathbf{1 1}$ & Harvesting \& threshing & 43 & 46 & 31 & 132 & 1.10 & VIII \\
\hline
\end{tabular}

Table 2 reveals practice wise scientific temperament of pulse growers towards cluster demonstration. It is clear that the mean score was highest in summer time of sowing (1.46) followed by use of improved variety (1.41), appropriate seed rate (1.35), selection of land (1.20), seed treatment (1.19), manure \& fertilizer management (1.15), weed management (1.11), harvesting \& threshing (1.10), insect and pest management (1.01) and lowest mean score was disease management (0.98).

Majority of respondents $(44.17 \%)$ had low scientific temperament level followed by (31.67 \%) had medium and only $(24.16 \%)$ had high scientific temperament of cluster demonstration respectively.

Practice wise mean score was highest in summer time of sowing (1.46) followed by use of improved variety (1.41), appropriate seed rate (1.35), selection of land (1.20), seed treatment (1.19), manure \&fertilizer management (1.15), weed management (1.11), harvesting \& threshing (1.10), insect $\&$ pest management (1.01) and lowest mean score was disease management (0.98).

\section{References}

Bathri A, Chaudhary S and Dubey A. 2014. Technological knowledge of cauliflower growers in Udaipur district of Rajasthan Journal of Extension Education. 17 \& 18(3): 124-127.

Chauhan. 2013. Training need of tribal farm women. Maharashtra Journal of Extension Education. XIV (6): 193-195.

Chawla S, Choubey A and Kumar S. 2014. Correlates if roll performance and training needs of farm women labour Journal of rural development. 11(1): 4958.

Dangi MS. 2016. Extent of Scientific Temperament of Beneficiaries under Chickpea Front Line Demonstration at Block Shahpura, District Jabalpur (M.P.), M.Sc. (Ag.) Thesis, JNKVV, Jabalpur.

Dour D, Meena S and Kumari K.2015. Impact of vegetable cultivation, income" organized by KVK on vegetable growers of Shabangi Khonde. Maharashtra Journal of Extension Education. 11(1): 81. 


\section{How to cite this article:}

Kulraj Raghuwanshi, Seema Naberia and Dubey, M.K. 2018. Extent of Scientific Temperament of Pulse Growers towards Cluster Demonstration in Rewa District M.P., India Int.J.Curr.Microbiol.App.Sci. 7(08): 2868-2871. doi: https://doi.org/10.20546/ijcmas.2018.708.302 